\title{
KETERLIBATAN BERBAGAI PIHAK DALAM UPAYA PELESTARIAN MANGROVE DI KAWASAN PESISIR
}

ABDUL WAHID

(105610512814)

UNIVERSITAS MUHAMMADIYAH MAKASSAR

Hutan mangrove mempunyai karakteristik yang unik di bandingkan dengan formasi hutan lainnya. Keunikan hutan tersebut terlihat dari habitat tempat hidupnya, juga keanekaragaman flora, yaitu Avicennia, Rhizhopora, Brugulera, dan tumbuhan lainya yang mampu bertahan hidup di salinitas air laut, dan fauna yaitu kepiting, ikan, jenis mollusca, dan lain lain. Hutan mangrove juga memiliki fungsi ekonomi, ekologi, dan sosial. Fungsi ekonomi yang ada di hutan mangrove yaitu penghasil kebutuhan rumah tangga, penghasil keperluan industri, dan penghasil bibit. Fungsi ekologisnya yaitu sebagai pelindung garis pantai, mencega intrusi air laut, sebagai habitat berbagai jenis burung, dan lain lain. (kustanti 2011)

Indonesia merupakan salah satu negara dengan kuantitas da variasi mangrove yang terbesar di dunia. Data tahun 1980 menyatakan bahwa wilayah mangrove indonesia seluas 4.251.011,03 hektar, namun ini terus menerus berkurang di karenakan penanganan yang kuang baik, juga penebangan mangrove yang berlebihan, mangrove tentu saja memberikan dampak ekonomis karena ayunya yang cukup kuat. Penebangan ini juga di lakukan karena wilayah yang tadinya di tumbuhi mangrove, di jadikan tambak, menjadi lahan eksplorasi arang, dan di konversi menjadi hutan kelapa sawit, baik oleh $\mathrm{p}$ [enduduk setempat juga para pengusaha yang datang dari luar wilayah tersebut dan mebuika lahan tambak besar besaran. Disinilah pemerintah diharapkan dapat meberikan kontribusi yang maksimal agar mangrove dapat tetap bertumbuh dan bertambah, namun menberikan dampak ekonomi yang maksimal bagi masyarakat di sekitarnya.

Mangrove memiliki manfaat penting bagi lingkungan pesisir, pengelolaan hutan mangrove adalah tanggung jawab bersama, perusahaan lokal harus berpartisipasi dalam pelestarian lingkungan, dan pemerintah daerah berkewajiban menjamin pelestarian lingkungan dengan baik melalui penegakkan hukum lingkungan dan partisipasi masyarakat dalam pelestarian lingkungan masih rendah. Indeks partisipasi dalam program rehabilitasi hutan mangrove berada pada tahap tekonisme yaitu suatu tingkat partisipasi dimana masyarakat di dengar danb di perkenankan berpendapat, tetapi mereka tidak memiliki kemampuan untuk mendapatkan jaminan bahwa pandangan mereka akan di pertimbangkan oleh pemegang keputusan. Hal ini akan menjadi ancaman keberlanjutan ekosistem hutan mangrove karena akan berimplikasi pada sense of belonging and sense of responsibility dari masyarakat terhadap pengelolaan hutan mangrove. 


\section{DAFTAR PUSTAKA}

Arief, A 2003. Hutan mangrove, fungsi dan manfaatnya, kanisius. Yogyakarta.

Demanhuri. 2001. Pengelolaan sumberdaya wilayah pesisir dan lautan secara terpadu. PT. Pradnya paramita. jakarta.

Nahruddin, Z. (2018). Collaboratif governance dalam pengelolaan lingkungan. INA-Rxiv. Open

Science framework 


\section{ABSTRAK}

Hutan mangrove memiliki karakteristik yang unik di bandingkan dengan fgormasi hutan lainnya. Keunikan hutan tersebut terlihat dari habitat tempat hidupnya. Hutan mangrove juga memiliki fungsi ekonomi, ekologi dan sosial. Fungsi ekonomis yang ada di hutan mangrove yaitu penghasil kebutuhan rumah tangga, penghasil kebutuhan industri dan lainnya. 